\title{
沿岸域の堆積泥を対象とした 示差熱分析手法の確立
}

\author{
高田 大貴 ${ }^{1} \cdot$ 森本 優希 ${ }^{2} \cdot \mathrm{TOUCH}^{\mathrm{N} A R O N G}{ }^{3} \cdot$ 中下 $\quad$ 慎也 ${ }^{4} \cdot$ 日比野 忠史 ${ }^{5}$ \\ 1学生会員 広島大学 大学院工学研究科社会基盤環境工学専攻（干739-8527 広島県東広島市鏡山1-4-1） \\ E-mail: m175472@hiroshima-u.ac.jp \\ 2正会員 広島大学 大学院工学研究科社会基盤環境工学専攻（干739-8527 広島県東広島市鏡山1-4-1） \\ E-mail: y-morimoto@hiroshima-u.ac.jp \\ 3 正会員 広島大学特任助教 大学院工学研究科（干739-8527 広島県東広島市鏡山1-4-1） \\ E-mail: narong-cambodia@hiroshima-u.ac.jp \\ 4正会員 広島大学助教 大学院工学研究科（干739-8527 広島県東広島市鏡山1-4-1） \\ E-mail:nakashita@hiroshima-u.ac.jp \\ 5正会員 広島大学准教授 大学院工学研究科（干739-8527 広島県東広島市鏡山1-4-1） \\ E-mail:hibinot@hiroshima-u.ac.jp
}

\begin{abstract}
示差熱計や熱重量計を使用した物質の熱反応特性の解明は広く行われている. 本研究では特に沿岸域に多 く堆積する底泥（堆積泥）を対象に示差熱分析を行い，分析手法を提案した。堆積泥中には無機物，有機 物が多種多様に含有されており, より精度の高い分析を行うために試料の前処理方法（乾燥法, 粒度調整 法）と最適な加熱速度，試料量の提案を行った。本実験から(1) $100^{\circ} \mathrm{C}$ 以下の揮発性物質を評価するための 乾燥法として, 凍結乾燥が最適であるが, $50^{\circ} \mathrm{C}$ 炉乾燥を凍結乾燥の代用として使用可能, (2) $75 \mu \mathrm{m}$ 以下に 試料を粒度調整することでバラツキの小さい測定が可能，(3)試料の吸熱・発熱反応を高精度でとらえるた めには5 10 $\mathrm{C} / \mathrm{min} の$ 加熱速度が適切, (4)試料量の適度な増加によるDTA（吸熱・発熱量）の増大により有 機物の特定が容易であることが明らかとなった。
\end{abstract}

Key Words : thermogravimetric analysis, elemental analysis, sediment, pretreatment, heating rate

\section{1. はじめに}

沿岸域に堆積する底泥（堆積泥）には植物プランク トンや陸水起源の有機物のみならず未処理下水等の生 活排水起源の有機物が多く含まれている．堆積泥は性 状の異なる有機物により構成されており，堆積泥中の 有機物の特定は困難になる場合が多い。しかし，有機 物の燃焼特性は分子構造によって特徵があることから， 有機物の燃焼特性を詳細に調べることで堆積泥に含ま れる有機物を特定できる可能性がある.

過去数十年にわたって，有機物に含まれる全有機炭 素量と有機物の燃焼で得られた燃焼減量との関係から 有機物性状の推定に関する研究が多く行われている (例えばPerie $\left.{ }^{1)}\right)$ ．分解速度が速く構造が不安定な有機 物（多糖類，タンパク質，脂肪等）は燃焼され易く, フミン酸, フルボ酸、ヒューミン等の腐植性有機物の 燃焼温度は高いことが知られている22.

本論文では粘土やシルト粒子に有機物が付着して構 成される堆積泥の燃焼特性を把握することを目的とし ている，示差熱計を用いて堆積泥中の粘土鉱物，有機 物の然焼特性を把握するに伴い，有機物組成が異なる
堆積泥を対象とした示差熱分析手法の確立を試みた.

\section{2. 有機物の推定法と示差熱分析の問題点の把握}

\section{(1) 堆積泥の定義とその構成}

有機物は金属イオンや粘土鉱物に化学吸着して錯体 （腐植性有機物）を形成する場合が多い，有機物は電 気的に不安定であるため，静電吸着により粘土鉱物に 付着した状態（安定化）を形成する。泥粒子の集合体 の間に補足された有機物も存在している。本研究では 粘土鉱物に有機物が付着して形成された $75 \mu \mathrm{m}$ 以下の粒 子を堆積泥として記述している.

有機物（炭素化合物）は C, H, N, S, O等の原子が 結合して形成されるため, その構造は無数に存在する. したがって個々の有機物の構造は複雑であり，特定は 不可能である。しかしながら，有機物は共通した構造 を持ち，その構造の燃焼により有機物の種類に応じた 燃焼特性を有している. Cuypersら 2)は有機物の示差熱か ら有機物の特定を試みており，脂肪酸，セルロース等 の構造が不安定な有機物は $290 \sim 310^{\circ} \mathrm{C}$ で最も燃焼（ピー クの出現）し，腐植性有機物であるフルボ酸，フミン 


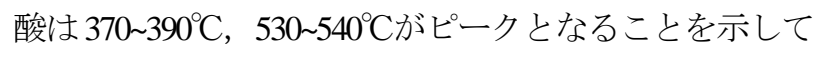
いる.フミン酸はフルボ酸よりも而熱性が高いため, より高温域で燃焼する。一方, 堆積泥は有機物の燃焼 の他に水分子, 水酸基, 構造水が組成物として含まれ ており，これらは燃焼により脱水する ${ }^{3)}$. 水分子は $100^{\circ} \mathrm{C}$ 以下, 水酸基は $100 \sim 200^{\circ} \mathrm{C}$, 構造水は $400 \sim 500^{\circ} \mathrm{C}$ で脱水する代表的な温度である。ちなみに，鉱物は生 成時に様々な結合構造を形成しており，H，O の結合形 態 (組成量) が鉱物に固有であるため, 脱水温度が異 なっている.

本論文では Cuyper ら 2)が行なった燃焼温度による構造 不安定な有機物と錯体状態にある腐植性有機物の区分 の結果をもとに, 堆積泥中の有機物に対する示差熱分 析の実用性について検討する.

\section{（2）既存の有機物含有量の測定方法}

有機物量の測定方法には簡易的な燃焼法である強熱 減量（IL : Ignition Loss），試料の加熱時に発生するガス から成分や成分量を直接測定する GC/MS（ガスクロマ トグラフ質量分析），試料ガスと水素の燃焼反応から 有機化合物を特定する GC/FID（水素炎イオン化分析） 等がある. Galbacsら ${ }^{4)}$, Cuyperら²)は示差熱分析（TGDTA）による重量と燃焼反応の相関関係から物質の特 定を試みていた。 また, 福井ららはCuypersら²)結果に 基づいてフミン酸やセルロース等の標準物質を堆積泥 と混合して燃焼実験を行い，燃焼特性から不安定な有 機物と腐植性有機物の分類方法（IL 300法）を提案した。 さらに，日比野らのは堆積泥から抽出した腐植性有機物 量を直接測定し, 燃焼特性から求められる腐植性有機 物量と比較して， $\mathrm{IL}_{300}$ 法の妥当性を示した.

\section{(3) TG-DTAによる燃焼試験}

示差熱計（島津製 DTG-60H） では有機物が燃焼した 時の発熱吸熱信号（DTA）と熱重量（TG）が測定（示 差熱と熱重量同時測定）される. DTAと TGの変化から 得られる吸熱・発熱反応から物質の相変化等が推定で きる. 有機物の熱分解, 脱水と鉱物の融解は吸熱反応 であり，有機物の酸化と酸化分解は発熱反応として現 れる. DTA のシグナルは吸熱時には下に凸，発熱時に は上に凸のピークが検出される. また, 脱水, 蒸発,

分解では TGが減少し, 酸化反応 $\left(\mathrm{O}_{2}\right.$ の結合) が起これ ば増加する. 有機泥の構成が複雑であるため, 堆積泥 を対象とした示差熱分析は困難であり, その分析手法

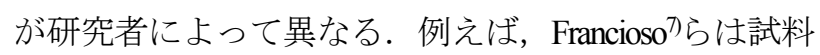
質量 $10 \mathrm{mg}$ を加熱速度 $10^{\circ} \mathrm{C} / \mathrm{min}$ で測定を行い, Galbacs ら 2)は試料質量 $5 \sim 10 \mathrm{mg}$ を加熱速度 $20^{\circ} \mathrm{C} / \mathrm{min}$ で測定してい る. すなわち, 測定に対する客観的な評価はできてい

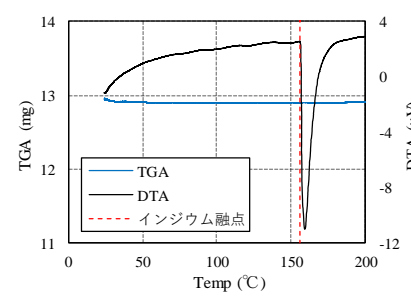

(a)インジウム (金属)

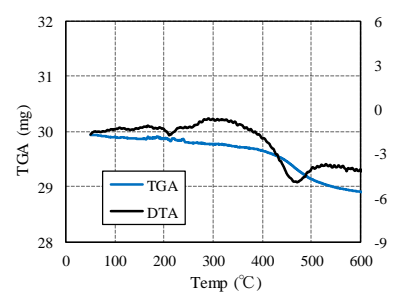

(c)まさ土

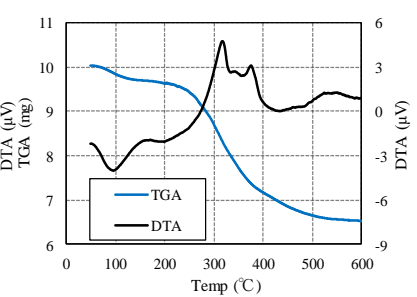

(b) リグニン

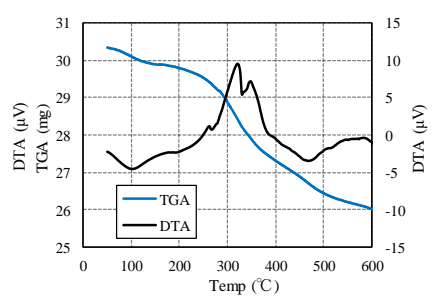

(d) リグニン+まさ土 図-1＼cjkstart標準物質の示差熱分析結果

ないのが現状である。

図-1 に標準物質である(a)インジウムと(b)リグニン, さらに土の主たる構成要素の粘土鉱物とされている(c) まさ土，(d)ではリグニン $10 \mathrm{mg}$ とまさ土 $20 \mathrm{mg}$ を混合し た場合の示差熱分析結果を示した.

\section{a) 金属（インジウム）の融解（図-1(a)）}

金属は揮発せず融解するため，熱重量（TG）は一定 となる、インジウムは融点に達すると急激に吸熱（融 解）し，除々に回復する収熱反応が明確に現れている。 インジウムは加熱と同時に周囲の熱を吸収して保熱し， 融点である $156.0^{\circ} \mathrm{C}$ に達すると融解する．融解温度の $156^{\circ} \mathrm{C}$ で直ちに吸熱し, 融解終了後に吸熱ピークが現れ る. 吸熱ピーク後は周囲の温度まで回復し, 融解前と 同様に保熱していく状態が理解できる. 図中の DTAの 初期值（ベースライン）との差が保熱量であり，吸熱, 発熱反応が無い場合には明確なピークは現れず，物質 内に除々に熱が蓄積（保熱）する.

\section{b) 有機物（リグニン）の燃焼（図-1(b)）}

リグニンは植物の細胞壁を構成する高分子の有機物 であるが，様々な組成分子の集合体である，リグニン の燃焼域では，吸着水（水分子）の脱水や組成の異な る有機物分子の燃焼が生じるため，様々な温度で減量 する. $70^{\circ} \mathrm{C}$ 付近から水分子の脱水に伴って吸熱し, 約 $200^{\circ} \mathrm{C}, 360^{\circ} \mathrm{C} 420^{\circ} \mathrm{C} ら$ 発熱反応が確認できる. DTA は緩やかな熱重量曲線とは異なり, 減量に依存し ない変化をしている．これは，高分子の腐植性有機物 の燃焼が継続して生じているからである.

\section{c) 粘土鉱物（まさ土）の燃焼（図-1(c)）}

粘土鉱物も金属，有機物と同様に保熱する特性があ る $\left(50^{\circ} \mathrm{C} \sim 300^{\circ} \mathrm{C}\right)$. 粘土鉱物はその構造上，水酸基や 構造水を含んでおり，脱水による吸熱を伴った減量が 生じる. 熱重量の勾配は $450^{\circ} \mathrm{C}$ 超えて大きくなってい 

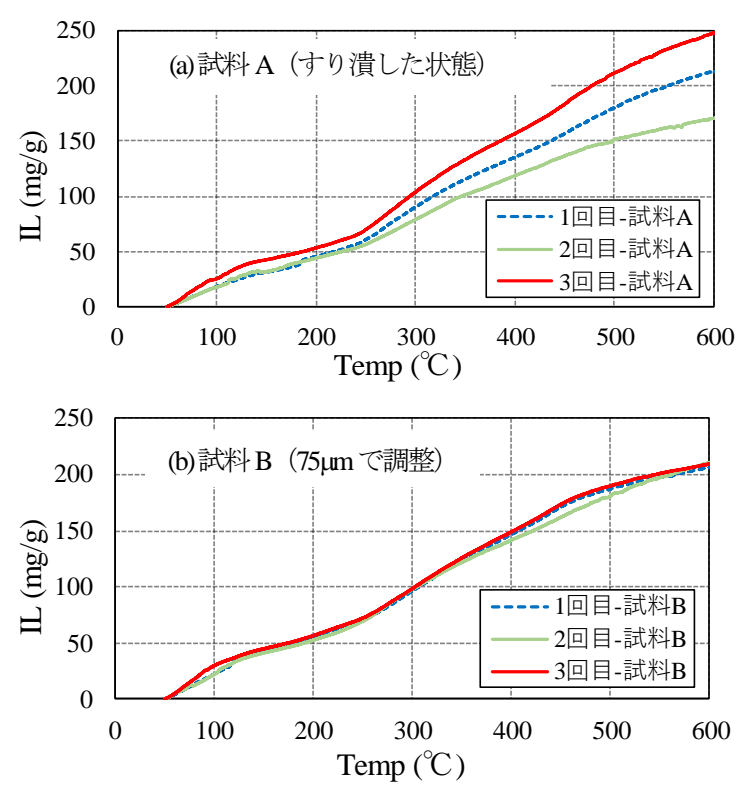

図-2 試料作成法の IL（=DTG/初期乾燥質量）による検討

る. DTAは熱重量曲線より約 $50^{\circ} \mathrm{C}$ 低い約 $400^{\circ} \mathrm{C}$ から吸熱 勾配が大きくなっている。 これはまさ土に含有される 構造水が脱水するからであると考えられる． $450^{\circ} \mathrm{Cから}$ の減量はリグニンの燃焼でも表れているが，リグニン では発熱を伴うのに対し，まさ土では吸熱を伴ってい る.

\section{d) リグニンーまさ土混合試料の燃焼（図-1(d)）}

図-1(b), (c)よりリグニンは約 $470^{\circ} \mathrm{C}$ に発熱のピークを, まさ土は $470^{\circ} \mathrm{C}$ に吸熱のピークを示している. リグニン 一まさ土混合試料では, 約 $380^{\circ} \mathrm{C}$ から DTAに吸熱反応が 現れ， $470^{\circ} \mathrm{C}$ で吸熱のピークを示すことから，吸熱反応 を示すまさ土の燃焼特性を反映していると言える。こ のことから, 図-1(d)のような発熱と吸熱が同時に生じ る混合物の示差熱分析では含有物の組成・量によって, 発熱・吸熱の DTAが合算されると考えられる.

堆積泥は多種多様の有機物と無機物で構成されてい るため, 測定される DTA は発熱, 吸熱, さらには試料 内に蓄積される保熱反応が合算された值を示している. したがって, DTA の変化特性から各含有物質の発熱・ 吸熱反応を推定するためには, 試料の前処理や示差熱 分析に用いる加熱速度, 試料質量を変化させて測定す る必要があると考えられる.

\section{3. 試料の前処理法の検討}

\section{(1) 試料作製法}

少量の試料を用いる示差熱分析では, 試料状態に依 存して測定結果にバラツキが生じることが考えられる. 特に保水能力の高い堆積泥では乾燥による収縮固化の ため, 試料の均一性を保つのは難しい。ここでは, 堆 積泥を $50^{\circ} \mathrm{C}$ 炉乾燥させた後に, $\mathrm{A}$ : 乳鉢ですり潰した状
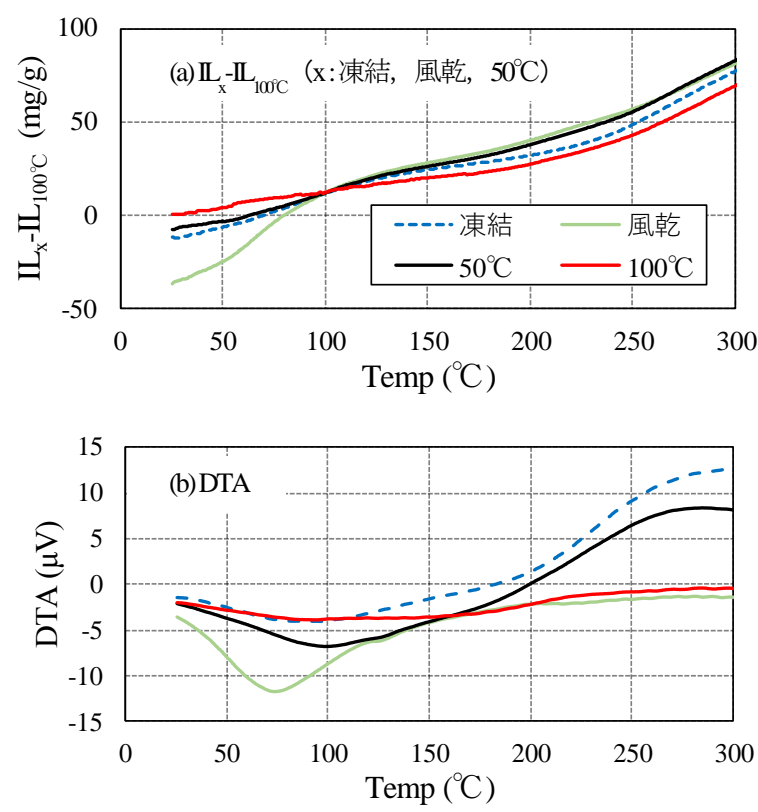

図-3 乾燥法を変えた示差熱分析結果

態（試料 A）と，B：すり潰した後 $75 \mu \mathrm{m}$ 以下に粒度調 整した状態（試料 B）の2条件で示差熱分析結果を比較 した. 2 条件で調整した試料に対して各々 3 回の示差熱 分析が行われた。 図-2 には(a)試料 A と(b)試料 B の燃焼 結果が示されている．TGはIL（=DTG/初期乾燥重量TG） に換算して示している. 固化した粗い粒子が含まれる 試料 A では 3 回とも異なる值が得られたのに対し,

$75 \mu \mathrm{m}$ 以下に粒度調整した試料 B では 3 回の測定で類似

(誤差 $1.0 \%$ 以下の差) の結果を得た．また試料 B での 減量は試料 A の最大值に近くなっており, 固化した状 態にある粒子には有機物の含有量が少ないことがわか る.この結果から乳鉢ですり潰せない粗い粒子は粘土 粒子を中心として乾燥収縮（固化）が起こると予想さ れる. 堆積泥では乾燥による収縮率が土粒子と有機物 で異なるため, すり潰した後の粒度調整により試料の バラツキを抑制する手法として有益である.

\section{(2) 試料の乾燥法}

\section{a) 乾燥法による残留物質の検討}

堆積泥の乾燥過程では有機物の揮発, 乾燥収縮等が 起こるため, 乾燥による試料の不均一化等の影響を排 除する必要がある。乾燥法の特性を把握するため, 凍 結乾燥，風乾 $\left(25^{\circ} \mathrm{C}\right.$ 室内乾燥），炉乾燥 $\left(50^{\circ} \mathrm{C}, 100^{\circ} \mathrm{C}\right)$ を比較した. 分析には福山内港で採取された有機物含 有量の多い堆積泥 5を使用した。 これまで含水比の測定 は $100^{\circ} \mathrm{C}$ 乾燥で行なってきたが, $50^{\circ} \mathrm{C} て ゙$ 炉乾燥を行った のは $100^{\circ} \mathrm{C}$ 以下で揮発する物質を検討するためである. $100^{\circ} \mathrm{C}$ 炉乾燥法と凍結乾燥法, 風乾法, $50^{\circ} \mathrm{C}$ 炉乾燥法を 比較することで $100^{\circ} \mathrm{C}$ 以下での蒸発と揮発状況を検討し た. 試料は前節に示した方法（試料B）で作成した. 各 乾燥法で作成した試料の示差熱分析と元素（CHNS）分 
析を合わせて行うことで $100^{\circ} \mathrm{C}$ ま゙残留物質の推定を 試みた。 なお，燃焼による減量原子は $\mathrm{C}, \mathrm{H}, \mathrm{N}, \mathrm{S}$ の 他に O があるが，示差熱分析が燃焼法であるため $\mathrm{O} の$ 測定はできない. 示差熱分析には，各試料をそれぞれ $30 \mathrm{mg}$ 使用し, 加熱速度は $5.0^{\circ} \mathrm{C} / \mathrm{min}$ として $850^{\circ} \mathrm{C}$ まて連 続的に昇温させた。

\section{b) 乾燥法の決定}

図-3 に各乾燥法によって作成された試料の(a) IL , (b)DTA が示されている. 図-3(a)では示差熱計において $100^{\circ} \mathrm{C}$ の加熱で水分は完全に蒸発するとして, $100^{\circ} \mathrm{C}$ 炉 乾燥試料の $\mathrm{IL}_{100}\left(100^{\circ} \mathrm{C}\right.$ におる $\mathrm{IL}$ ）を基準としており, $100^{\circ} \mathrm{C}$ 炉乾燥と各乾燥法での $100^{\circ} \mathrm{C}$ までの減量差は, 揮 発性物質あるいは水分の気化によるものとする．なお， $100^{\circ} \mathrm{C}$ 炉乾燥試料で $100^{\circ} \mathrm{C}$ 加熱時の減量 $10 \mathrm{mg} / \mathrm{g}$ は試料作 成段階での水分の付着量であると考えられる. 凍結乾 燥では水分が 98\%以上除去できることから, 凍結乾燥 での $100^{\circ} \mathrm{C}$ 炉乾燥試料との差（IL） は揮発性物質, $100^{\circ} \mathrm{C}$ 付近の吸熱ピーク（DTA）は揮発性物質の気化として 考えられる(図-3(b)).

また, $50^{\circ} \mathrm{C}$ 乾燥と減量の差が小さいことから $50^{\circ} \mathrm{C}$ 炉 乾燥試料は凍結乾燥と同等の乾燥法として用いること ができる.ただし, 凍結乾燥試料と $50^{\circ} \mathrm{C}$ 炉乾燥試料に 含まれる揮発性物質は約 $20 \mathrm{mg} / \mathrm{g}$ であるが, DTA では両 試料で吸熱量が異なっている. 凍結乾燥は乾燥時に試 料の構造を保持する $\left.{ }^{8}\right)$ が，50ㄷ乾燥においては乾燥収縮 が生じることで試料が燃焼しにくくなる. 試料の固化 は DTA における吸熱のピークや大きさの現れ方を変化 させる可能性がある. 水分が残る $25^{\circ} \mathrm{C}$ 風乾における DTA での約 $80^{\circ} \mathrm{C}$ 付近のピークは主に水分の脱水による 吸熱であると推定できる.ちなみに, $100^{\circ} \mathrm{C}$ 以上での DTA の変化は基本的に乾燥した試料の状態に依存した 発熱反応を示している. 凍結乾燥試料では伝熱しやす い状態が現れており，固結試料では，伝熱しにくい状 態にあると推定される.

図-4には各試料のCHNS 分析結果が示されている，C の $100^{\circ} \mathrm{C}$ 炉乾燥試料之凍結乾燥試料との差は $8 \mathrm{mg} / \mathrm{g}$ 程度 である. $\mathrm{H}+\mathrm{S}$ の $100^{\circ} \mathrm{C}$ 乾燥試料との差が約 $11 \mathrm{mg} / \mathrm{g}$ で同程 度であり, 揮発物質量 $\left(\mathrm{IL}_{100}\right)$ が $50^{\circ} \mathrm{C}$ 炉乾燥試料と同程 度であったことから凍結乾燥試料でのCの差 $8 \mathrm{mg} / \mathrm{g}$ はサ ンプリング誤差として考えられる. また, 風乾， $50^{\circ} \mathrm{C}$ 乾燥による C の減量に有意差がないことから, 本試料 では揮発性物質は無機物であると考えられる，100ㄷ户 乾燥では $\mathrm{S}$ と $\mathrm{H}$ の減量が顕著であることから, 揮発性 物質は硫黄化合物 $\left(\mathrm{H}_{2} \mathrm{~S}, \mathrm{~S}\right.$ 等）であると推定される. 乾燥が不十分な $25^{\circ} \mathrm{C}$ 風乾で $\mathrm{H}$ の残留が多いことから, 凍結, $50^{\circ} \mathrm{C}$ 乾燥試料との $\mathrm{H}$ の差は水分量として推定さ れる. 凍結， $50^{\circ} \mathrm{C}$ 乾燥試料では IL，DTA とも同じと見 なせる特性を有しており, 乾燥法として凍結乾燥, ま

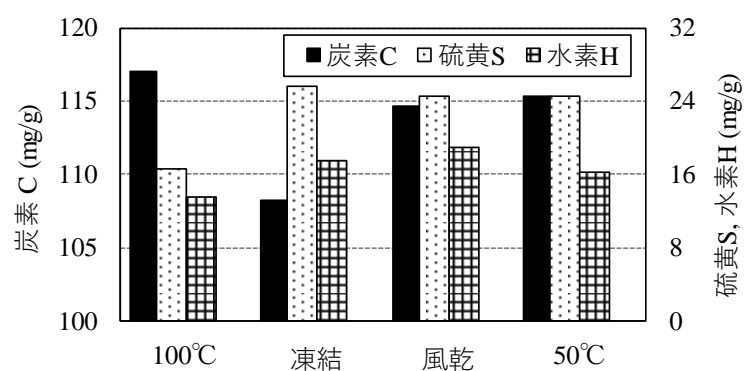

図-4 各乾燥試料の CHNS 分析結果
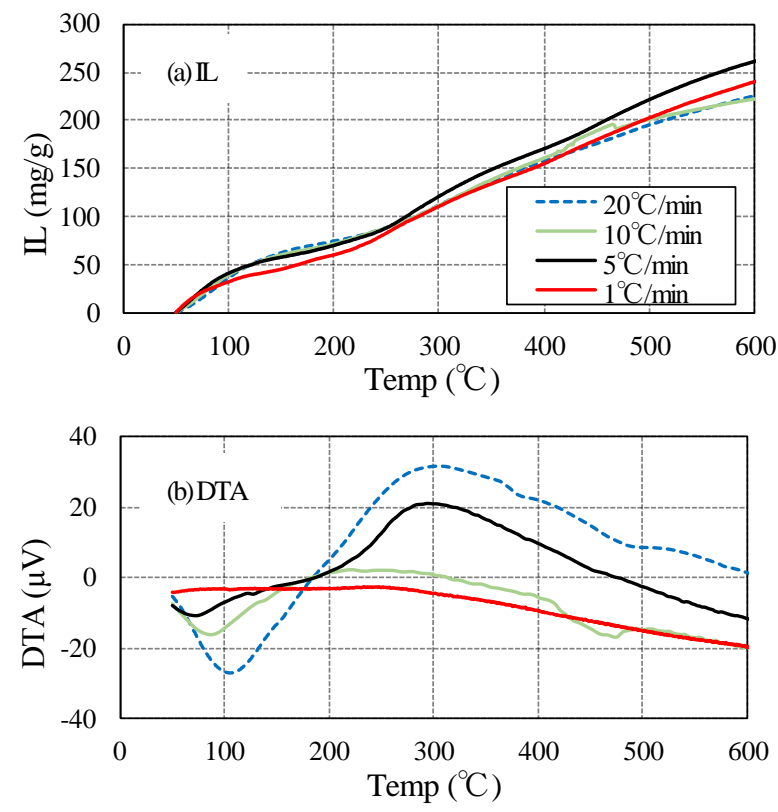

図-5 異なる加熱速度による示差熱分析結果(30mg)

たは $50^{\circ} \mathrm{C}$ 炉乾燥を用いることが妥当である.ただし， $50^{\circ} \mathrm{C}$ 炉乾燥により試料が収縮固化することを考えれば 凍結乾燥法が最適と判断される.

\section{4. 示差熱分析手法の検討}

\section{(1) 加熱速度に対する燃焼の依存度}

堆積泥中には発熱物質や吸熱物質が多様に含まれて いるため, 加熱速度に依存して発熱，吸熱が重なり燃 焼物質の特性（DTAのピーク等）を見逃す機会が増し ていくことが予想される.ここでは試料 $30 \mathrm{mg} に$ 対して 加熱速度を $20,10,5,1^{\circ} \mathrm{C} / \mathrm{min}$ に変化させて示差熱分析 を行い, 得られたIL-DTAの関係から適切な加熱速度を 検討した.

\section{a) サンプリング状況}

図-5に加熱速度を変化させて示差熱分析した時の(a) ILと(b) DTAを示す。これまでの分析では同試料におい て減量（IL）の顕著な差は生じていないことから，図一 5(a)での各加熱速度に対するILの差は試料のバラツキ (サンプリング誤差) として考えられる．また，400ㄷ 以上で然焼する難燃性物質（リグニン等の有機物, 構 造水, 炭酸カルシウム等) の減量が各々の試料で異な ることから，土粒子の組成が異なっていることが予想 
できる. 特に $10^{\circ} \mathrm{C} / \mathrm{min}$ での燃焼では $420^{\circ} \mathrm{C}$ からのDTAの 変化が他の試料と異なるため, 他の試料にない吸熱反 応を伴う物質が含有されていることがわかる。

\section{b) 加熱速度差によるDTAの変化}

図-5(b)に示すDTAでは $100^{\circ} \mathrm{C}$ 以下で起こる揮発過程に おいて加熱速度が速くなるにつれ吸熱量が大きく, か つピークが高温側にずれていることがわかる. 吸熱開 始温度が等しいことから揮発物質は同質であると推定 できる．吸熱のピークの大きさは物質の反応熱と加熱 量の和を示している. 低い加熱速度では加熱量, 速い 加熱速度では反応熱が卓越する. $1^{\circ} \mathrm{C} / \mathrm{min}$ では $100^{\circ} \mathrm{C}$ 以下 でのDTAに変化がなく, 加熱速度が遅いと吸熱現象が 現れなくなることがわかる，吸熱ピークが現れないの は, 揮発での熱利用よりも加熱による熱供給が多いた めである.さらに, $1^{\circ} \mathrm{C} / \mathrm{min}$ では発熱 $\left(200^{\circ} \mathrm{C}\right.$ 以上) によ る保熱も小さく, 低加熱速度では吸熱と同様に発熱に よる有機物への保熱もDTAの変化に現れにくいことが わかる。 したがって, 低加熱速度による燃焼では物質 の熱反応が現れなくなるため, 適当な速度の加熱が必

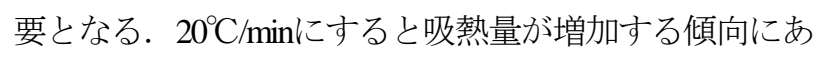
り, 加熱速度が遅い場合とは逆に速い場合には吸熱分 を周辺温度で補完できない状態が生じる.

\section{c) DTA特性}

腐植性有機物と構造不安定な有機物の違いはDTAの 変化特性から判断できる. 不安定有機物の燃焼によっ て堆積泥は発熱に伴い減量する. 発熱減量前の物質の 保熱量と発熱減量後の物質の保熱量は不安定有機物の 減量分だけ小さくなる. 全ての試料において $300^{\circ} \mathrm{C}$ を越 えると減量に伴ってDTAは下げ勾配となる（図-5）。 腐植性有機物の燃焼域でのDTAの低下は腐植性有機物 の燃焼に伴った発熱，不安定有機物の燃燒に伴う保熱 量の低下, 構造水の蒸発に伴った吸熱（図-1(c)）によ る影響を含んでおり, 構造水の脱水に伴う熱供給の停 滞等がDTAを低下させることを示している．また， $300^{\circ} \mathrm{C}$ を越えて燃焼する物質では図-1(a)に示したインジ ウムのような明確なピークを持つ熱量変化は現れない. これは個々の有機物が高分子であり，かつ燃焼温度の 異なる有機物や難燃性物質が種々に含まれているため である。

\section{d) 加熱速度の決定}

$20^{\circ} \mathrm{C} / \mathrm{min}$ の加熱速度では大きな保熱量がDTAに現れて いる. しかし, 加熱速度が速い燃焼では吸熱からの回 復が遅れる（ピークが高温側にずれる）ため, 保熱一 の転向が遅くなり, 吸熱反応後の発熱反応を捉え難く なる. 発熱反応が起こる構造不安定な有機物の燃焼で は, $200^{\circ} \mathrm{C}$ 前後での変化 (吸熱 $\rightarrow$ 発熱過程) の勾配変化 を捉えることができない $20^{\circ} \mathrm{C} / \mathrm{min} の$ 加熱速度は適当では ないと判断される. $5^{\circ} \mathrm{C} / \mathrm{min}$ と $10^{\circ} \mathrm{C} / \mathrm{min}$ では吸熱のピーク
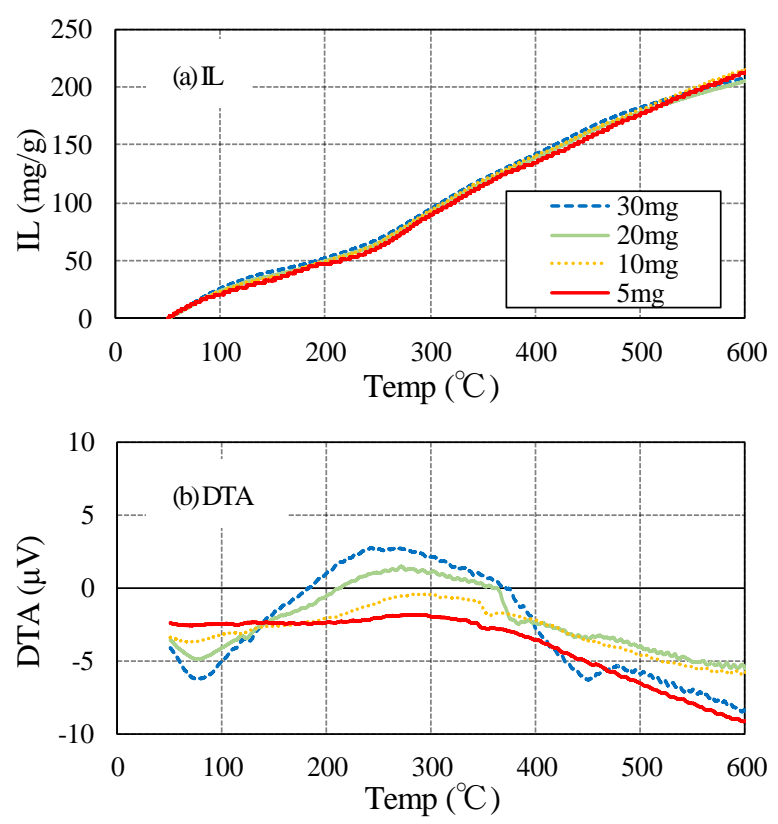

図-6 異なる試料量による示差熱分析結果

が早期に現れることから，吸熱反応に引き続く発熱反 応を捉えるには適当な加熱速度と判断できる。

\section{（2）試料量に対する燃焼の依存度}

試料の燃焼は表面から起こることから, 確実に燃焼 させるための適切な試料量を決定することが必要とな る. 試料量は $30 \mathrm{mg}, 20 \mathrm{mg}, 10 \mathrm{mg}, 5 \mathrm{mg}$ として示差熱分 析を行い，得られたIL-DTAの関係から試料量を検討し た. 加熱速度は燃焼物質の種類と量に対応させて変化 させる必要があるが，本検討では前節での結果から加 熱速度として5 $5^{\circ} \mathrm{C} / \mathrm{min}$ 採用した.

\section{a) 試料量の差によるDTAの変化}

図一6はは試料量を変えて示差熱分析をした時の(a) IL と(b) DTAが示されている. 本分析においてはILの差が 小さいことから，4つの分析試料のサンプリングは均一 と言える. ILに対する試料量の増加の影響が小さいこ とは, DTAが試料重量に依存した変化であることを示 している. 寸なわち, 本分析結果ではDTAの差は試料 量の差，効果として考えることができる.

図-6(b)から揮発による吸熱量，および有機物燃焼に よる発熱量は試料重量に依存して大きくなっているこ とがわかる.この傾向は加熱速度に対する依存性と類 似の特性を示している. 加熱速度の増大によってDTA のピークは高温側へずれた. 一方, 脱水によるDTAピ

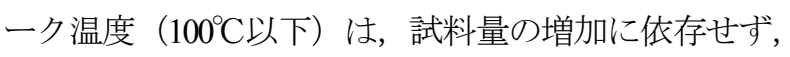
約 $80^{\circ} \mathrm{C}$ に現れている.さらに, $300^{\circ} \mathrm{C}$ までの不安定有機 物の燃焼では試料量の増加に伴って発熱のピークが低 い温度側で現れている。これらのことはDTAに現れる 熱量（発熱・保熱量）は物質量と加熱速度に依存する ことを示している. 加熱速度が一定のとき, 試料量が 多いほど発熱・保熱量は大きくなる。 また, 加熱速度 
が速い程, 試料が短時間で昇温されるため, 加熱速度 が遅い時と比較して単位時間当たりに燃焼する有機物 量が多くなり, 発熱・保熱量が大きくなる.しかし, 加熱速度が速くなると保熱時間（量）は短くなり, 燃 焼特性の変化を捉えにくくなる $\left(1^{\circ} \mathrm{C} / \mathrm{min}\right.$ では $20^{\circ} \mathrm{C} / \mathrm{min}$ の 20倍の時間，熱を受けている）。

\section{b) 試料量の決定}

$5 \mathrm{mg}$ でのDTAは $1{ }^{\circ} \mathrm{C} / \mathrm{min} の \mathrm{DTA}$ （図-5）と同じ傾向を示 しており, 少試料量 (5mg) の燃焼量では, 加熱速度が 遅いことと同じように, DTAの変動が小さいことから 適当な重量ではない, 吸熱, 発熱反応ともに保熱容量 と熱供給速度がDTAの変化を決定しており, 最適な重 量と加熱速度の組み合わせがあることがわかる，今回 の検討では $5^{\circ} \mathrm{C} / \mathrm{min}$ の加熱速度を適当としており，この 加熱速度に適応する試料量が存在する. 堆積泥が熱収 縮すると有機物が無機物内に閉じ込められるために, 重量や加熱速度によって保熱量が変動すると考えられ る. 不安定有機物の燃焼によるDTAの増大は熱収縮し た無機物内に反応熱が保持されるためと考えられる. DTAの増大は試料重量に依存して現れていることから， 試料量が多くなると堆積泥中の有機物の発熱反応を区 別でき, 不安定有機物と腐食性有機物の差は判定はし 易くなる，ただし，有機物個々の燃焼特性は平均化 （平坦化）され判定できなくなる. 試料量は目的に合 わせて決定することが必要となる.

\section{5. おわりに}

本研究で得られた結論を以下にまとめる.

(1) $100^{\circ} \mathrm{C}$ 以下の揮発性物質を評価寸るための乾燥法とし て, 凍結乾燥が最適であるが， $50^{\circ} \mathrm{C}$ 炉乾燥を凍結乾 燥の代用として使用できる.

(2) 試料を $75 \mu \mathrm{m}$ 以下に粒度調整することでバラツキが 小さく，堆積泥中の有機物量を十分に反映した分析
を行うことが可能である.

(3) $5 \sim 10^{\circ} \mathrm{C} / \mathrm{min}$ の加熱速度を使用することで堆積泥の発 熱，吸熱反応を高精度でとらえることができる.

(4) 試料量が多いほど DTAの反応が顕著であることから， 20 30mg 程度の試料量を使用することが適切である.

謝辞：本研究は科学研究費補助金（課題番号： 15H05221，16H04418 および 16K14311）による助成を受 けた.ここに記して謝意を表する.

\section{参考文献}

1) Perie, C. and R. Ouimet : Organic carbon, organic matter and bulk density relationships in boreal forest soils, Canadian Journal of Soil Science, Vol.88, No.3,pp.315-325, 2008.

2) Cuypers, C.T. Grotenhuis, K.G.J Nierop, E.M. Franco, A.D. Jager and W. Rulkens : Amorphous and condensed organic matter domains : the effect of persufate oxidation on the composition of soil/sediment organic matter, Chemosphere, Vol.48, pp. 919-931, 2002.

3) 加藤忠蔵: 粘土鉱物の吸着水 - 層間水 - 構造水の状態, 粘土科学, 第 29 巻, 第 3 号, pp.118-128, 1989.

4) Galbacs, G. T. Kantor,L. Moens andR. Dams: Mass spectrometric studies of thermal decomposition products of reference materials for use in solid sampling atomic spectrometry, Spectrochimica Acta, Vol. 53, Part B, pp.1335-1346, 1998

5) 福井勝吾, 中岡孝行, 中下慎也, 日比野忠史 : 有機物の分解 過程を考慮した河口域に堆積する有機泥性状に関する研 究, 土木学会論文集 B1（水工学）,Vol.69,pp.1417-1422, 2013.

6) 日比野忠史, 太刀内紘平, TOUCHNARONG, 中下慎也 : 沿 岸域に堆積する有機泥に含まれる有機物の分類法, 土木学 会論文集 B2（海岸工学），Vol. 70, No. 2, pp. I_1101-I_1105, 2014.

7) Ornella Francioso, Daniela Montecchio, Paola Gioacchini, Claudio Ciavatta:Thermal analysis (TG-DTA) and isotopic characterization $\left({ }^{13} \mathrm{C}-{ }^{15} \mathrm{~N}\right)$ of humic acids from different origins, Applied Geochemistry Vol.20, pp.537-544, 2005

8) 三浦哲彦, 山寺彰, 日野剛徳 : 間隙径分布の測定に基づ く海成粘土の圧縮特性に関する考察, 土木学会論文集 No.624, III-47, pp.203-215, 1999.

(2017.3.15 受付)

\section{PROPOSAL OF DIFFERENTIALTHERMAL ANALYSIS METHOD FOR LITTORAL SEDIMENTS}

\section{Hiroki TAKATA, Yuki MORIMOTO, Narong TOUCH, Shinya NAKASHITA and Tadashi HIBINO}

Differential thermal analysis (TG-DTA) has been widely used for identifying the organic matter characteristics of sediment; however, different methods of TG-DTA have been conducted. This study aims to propose the method of TG-DTA for the analysis of littoral sediment. Namely, methods of sample pretreatments (i.e drying and sieving), optimum heating rate, and sample amount were proposed. It was found out that (1) $50^{\circ} \mathrm{C}$ drying sample could be used instead of freeze drying sample, which can evaluate volatile substances below $100^{\circ} \mathrm{C},(2)$ a more accurate TG-DTA could be obtained by using the sample smaller than $75 \mu \mathrm{m}$, (3) endothermic / exothermic reactions could be clearly examined at the heating rate of $5-10^{\circ} \mathrm{C} / \mathrm{min}$, and (4) increasing weight of sample resulted in a clear variation of DTA, leading to a easier identification of organic matter present in sediments. 